\title{
Absence of Gastrointestinal Absorption or Urinary Excretion of Aluminium from an Allantoinate Complex Contained in Two Antacid Formulations in Patients with Normal Renal Function
}

\author{
Olivier Guillard ${ }^{1}$, François Huguet ${ }^{1}$, Bernard Fauconneau ${ }^{1}$, Alain Piriou $^{1}$ and Alain Pineau ${ }^{2}$
}

1 Centre d'Etude et de Recherche sur les Xénobiotiques, EA 1223, Laboratoire de Biochimie et de Toxicologie, Hôpital Jean Bernard, Poitiers, France

${ }^{2}$ Laboratoire de Toxicologie, Faculté de Pharmacie, Nantes, France

Summary: We studied the plasma and urinary excretion levels of aluminum (Al) on day 0,10 and 30 in 79 patients with gastrointestinal symptoms and normal renal function who were receiving a complex based on $\mathrm{Al}$ allantoinates $\left[\mathrm{C}_{4} \mathrm{H}_{5} \mathrm{~N}_{4} \mathrm{O}_{3} \mathrm{Al}(\mathrm{OH})_{2}\right]$ and $\left[\mathrm{C}_{4} \mathrm{H}_{5} \mathrm{~N}_{4} \mathrm{O}_{3} \mathrm{Cl} \mathrm{Al} 2(\mathrm{OH})_{4}\right]$. We evaluated the extent of $\mathrm{Al}$ absorption after repeated administration of this complex in two antacid formulations, Ulfon Lyoc ${ }^{\circledR}$ in lyophilised tablet form (group 1; $\mathrm{n}=40$ ) and Ulfon ${ }^{\circledR}$ suspension (group $2 ; \mathrm{n}=39$ ). The total Al load for each antacid and patient was $512 \mathrm{mg}$ daily for a total of $15360 \mathrm{mg}$ during the 30-day treatment. No significant rise in plasma Al concentration was noted with either formulation between day 0 and 10 , day 0 and 30 or day 10 and 30, nor was there any significant increase in urinary excretion levels. Al absorption was not increased and no toxic effects were noted, indicating that such formulations are suitable for long-term therapy in patients with gastrointestinal symptoms.

\section{Introduction}

Aluminium (Al), a ubiquitous contaminant, is routinely used in antacid form to prevent or treat gastric lesions, gastro-oesophageal reflux or oesophagitis in patients with normal renal function $(1,2)$. Studies have shown an increase in serum $\mathrm{Al}$ levels in healthy subjects or in patients with chronic renal failure after oral ingestion of various compounds usually containing $\mathrm{Al}$ hydroxide (3) or sucralfate (4), respectively, as phosphate binders.

Aluminium toxicity syndrome was described in 1976 by Alfrey et al. (5) in the context of dialysis encephalopathy, but it can also occur in patients with impaired excretory renal function not yet requiring haemodialysis $(6,7)$; these effects indicate that the gastrointestinal tract plays an important role in $\mathrm{Al}$ absorption from phosphate-binding drugs. Moreover, high concentrations of the metal have been found in brain tissues of healthy subjects treated with Al hydroxide (8).

This study was conducted over a 30-day period in patients with gastrointestinal symptoms and normal renal function to determine the levels of intestinal $\mathrm{Al}$ absorption from the allantoinate-based complexes $\left[\mathrm{C}_{4} \mathrm{H}_{5} \mathrm{~N}_{4} \mathrm{O}_{3} \mathrm{Al}(\mathrm{OH})_{2}\right]$ and $\left.\mathrm{C}_{4} \mathrm{H}_{5} \mathrm{~N}_{4} \mathrm{O}_{3} \mathrm{Cl} \mathrm{Al} 2(\mathrm{OH})_{4}\right]$ contained in two different antacid formulations: Ulfon Lyoc ${ }^{\circledR}$ lyophilised tablets and Ulfon ${ }^{\circledR}$ suspension, both manufactured by L. Lafon Laboratories (F-94701 Maisons-Alfort Cedex France). The study was performed because the effects of repeated $\mathrm{Al}$ ingestion are largely un- known in such patients, and long-term therapy therefore represents a potential risk.

\section{Patients and Methods}

Subjects

After approval by the Local Ethics Committee, the study protocol was carried out at the Jean Bernard Hospital, Poitiers, France. Experiments were performed in 79 patients (two groups) with gastrointestinal symptoms, each of whom gave informed written consent. The first group consisted of 40 patients ( 20 men, 20 women; mean age \pm standard deviation $44.05 \pm 11.94$ years, range 20-75) weighing between 50 and $95 \mathrm{~kg}$ (mean \pm standard deviation 68.5 \pm 13.1 ). The second group ( 19 men, 20 women; mean \pm standard diviation $52.47 \pm$ years, range 23-75) weighed between 47 and $90 \mathrm{~kg}$ (mean \pm standard deviation $67.6 \pm 12.59$ ).

The 79 patients were included in the study on the basis of interviews concerning their past medical history and the existence of painful symptoms warranting 30-day prescription of an antacid. The patients excluded had renal disease (serum creatinine measurement), ulcer complications (bleeding, perforation), recorded hepatitis or cardiovascular problems. During the selection process, plasma was screened for Australia antigen and HTLV III antibodies. The following medications were prohibited during the treatment: acetylsalicylic acid, anti-inflammatory agents, other antacids (e. g. cimetidine, ranitidine) and $\mathrm{Al}$ salts. Patients were told to eat three regular meals per day and to avoid foods producing ulcer symptoms. Alcoholic beverages were not allowed.

\section{Drug composition and treatment}

The antacids contained a complex based on Al allantoinates, a chemical combination of Al dihydroxy $(900 \mathrm{mg})$ and chlorhydroxy $(100 \mathrm{mg})$ allantoinates with calcium carbonate $(500 \mathrm{mg})$. This water-insoluble complex (9) was presented in two different formulations, each containing $128 \mathrm{mg}$ of $\mathrm{Al}$. Patients in group 1 orally ingested Ulfon Lyoc ${ }^{\circledR}$, a lyophilised tablet which melts under the 
tongue without water, and group 2 received Ulfon ${ }^{(1)}$ suspension in small bags. A tablet or bag was administered one hour after breakfast, lunch and dinner and before bedtime (four doses per day for 30 days) which corresponds to $512 \mathrm{mg}$ of Al per day, the therapeutic dose currently used in antacids for gastrointestinal symptoms.

\section{Procedures and study design}

The main assessment criteria were plasma and urinary Al concentrations determined on day 0 (baseline and onset of treatment), 10 and 30 (end of treatment). All blood samples were obtained from fasting patients before antacid intake. Complementary blood tests were performed on day 0 and 30 for creatinine, glucose, calcium, magnesium, phosphorus, sodium, potassium, iron. All patients underwent in-depth medical tests on day 0 and 30 . Patients would have been excluded from the study if they had presented a serious illness, required surgery or had side effects associated with the treatment.

\section{Blood and urine sampling and assay}

As $\mathrm{Al}$ is a ubiquitous element, great care was taken at all stages of preparation to avoid any risk of sample contamination. The procedure used has already been described by Guillard et al. (10). No glassware was used. Polystyrene tubes and polyethylene bottles (PolyLabo and Paul Block, Strasbourg, France), used respectively for blood and urine collection, were washed in acid $\mathrm{HCl}(6.30$ mol/) (Merck, Suprapur, Darmstadt, Germany), rinsed with "ultrapure" water and checked for $\mathrm{Al}$ contamination (Al level less than $0.037 \mu \mathrm{mol} / \mathrm{l}$ ). Blood samples were obtained from each patient (two tubes for each patient) using a $0.7 \mathrm{~mm}$ Vygon ${ }^{\circledR}$ "epicranium" needle (Ecouen, France) designed to allow blood to enter drop by drop into 3-ml heparinized polystyrene tubes (Al-free heparin). After centrifugation, plasma was immediately stored at $-20^{\circ} \mathrm{C}$. For 24-h urine, successive micturitions were collected to limit contamination, as recommended by Griffin (11), and samples were stored at $-20^{\circ} \mathrm{C}$ until analysed. Al measurements were performed on a Perkin-Elmer Zeeman 5000 equipped with a HGA 500 graphite atomizer and an AS 40 autosampler (all from Perkin-Elmer Corp., Norwalk, CT, USA). The technique described for element assay in blood has been applied to urine assay with a detection limit of $0.03 \mu \mathrm{mol} / 1$.

\section{Quality assurance}

Each Al calibration was monitored with two quality controls, one for plasma (Seronorm ${ }^{\circledR}$, Nycomed, Oslo, Norway) and the other for urine (Bio-Rad ${ }^{\circledR}$, Anaheim, CA, USA). In addition, analytical performance was monitored by participation in two interlaboratory surveys: the Guildford trace element external quality assessment scheme (12) (Guildford, Surrey, UK) and the "Centre de Toxicologie du Québec" Interlaboratory comparison program (13). The accuracy for these two quality assessment schemes is about $10 \%$.

\section{Statistics}

Data management and statistical calculation were carried out using the 4.02 version of Statgraphics software (S. T. S. C., Anaheim, CA, USA). Results are reported as mean $\pm \mathrm{SD}$. Data were analysed using Student's $t$-test for paired samples to assess significant differences for each group between day 0 (baseline) and 10, 0 and 30 and 10 and $30 . P<0.001$ was considered statistically significant.

\section{Results}

In table 1 , there were no significant increases over baseline plasma $\mathrm{Al}$ levels (day 0 ) in patients of either group on day 10 or 30 , and the range of $\mathrm{Al}$ levels during both treatments $(0.12$ to $0.90 \mu \mathrm{mol} / \mathrm{l})$ remained close to baseline values $(0.17$ to $0.44 \mu \mathrm{mol} / \mathrm{l})$. Similar results were found for urinary $\mathrm{Al}$ excretion (tab. 2), with values on day $10(0.04-0.32 \mu \mathrm{mol} / 24 \mathrm{~h})$ and $30(0.05-0.33$ $\mu \mathrm{mol} / 24 \mathrm{~h}$ ) showing no significant differences from the baseline (day 0 ) values $(0.05-0.29 \mu \mathrm{mol} / 24 \mathrm{~h}$ ).

No significant differences in biochemical quantities were noted for any patient in either group between day 0 and 30.

\section{Discussion}

Aluminium, a ubiquitous contaminant, is neurotoxic in patients with chronic renal failure (5). The renal system is primarily responsible for aluminium excretion (16). High oral doses of Al-containing phosphate binders are prescribed for these patients $(5,17)$, and Al hydroxide, the compound most widely used in the formulation for phosphate regulation, may increase Al uptake (18), leading to neurodegenerative disorders (5) and other toxic symptoms including microcytic and vitamin $\mathrm{D}$-resistant osteomalacia. Sucralfate, the phosphate binder of choice in patients with uraemia and peptic ulceration (4), often

Tab. 1 Plasma aluminium concentration in patients determined on day 0,10 and 30 .

\begin{tabular}{llll}
\hline Day & \multicolumn{2}{l}{ Plasma aluminium $(\mu \mathrm{mol} / \mathrm{l})$} \\
\cline { 2 - 4 } & $\begin{array}{l}\text { Group 1 } \\
\text { (range) }\end{array}$ & $\begin{array}{l}\text { Group 2 } \\
\text { (range) }\end{array}$ & $\begin{array}{l}\text { Reference } \\
\text { values } \\
(14,15)\end{array}$ \\
\hline 0 (baseline) & $0.22 \pm 0.06$ & $\begin{array}{c}0.25 \pm 0.09 \\
(0.17-0.44)\end{array}$ & $0.07-0.43$ \\
& $(0.18-0.41)$ & $(0.17$ & \\
10 & $0.21 \pm 0.05^{\mathrm{a}}$ & $0.24 \pm 0.08^{\mathrm{a}}$ & \\
& $(0.12-0.37)$ & $(0.16-0.40)$ & \\
30 & $0.23 \pm 0.08^{\mathrm{b}}$ & $0.26 \pm 0.02^{\mathrm{b}}$ & \\
\hline
\end{tabular}

Group 1: $n=40 ;$ Group 2: $n=39$ with mean \pm SD and range. a: Not significantly different between day 0 (baseline) and day 10 . b: Not significantly different between day 0 (baseline) and day 30 .

Tab. 2 Urinary aluminium excretion in patients determined on day 0,10 and 30 .

\begin{tabular}{llll}
\hline Day & \multicolumn{2}{l}{ Aluminium excretion $(\mu \mathrm{mol} / 24 \mathrm{~h})$} \\
\cline { 2 - 4 } & $\begin{array}{l}\text { Group 1 } \\
\text { (range) }\end{array}$ & $\begin{array}{l}\text { Group 2 } \\
\text { (range) }\end{array}$ & $\begin{array}{l}\text { Reference } \\
\text { values } \\
(15)\end{array}$ \\
\hline 0 (baseline) & $0.11 \pm 0.04$ & $0.12 \pm 0.04$ & $0.08-0.27$ \\
& $(0.05-0.29)$ & $(0.05-0.18)$ & \\
10 & $0.12 \pm 0.05^{\mathrm{a}}$ & $0.14 \pm 0.06^{\mathrm{a}}$ & \\
& $(0.05-0.24)$ & $(0.04-0.32)$ & \\
30 & $0.13 \pm 0.03^{\mathrm{b}}$ & $0.14 \pm 0.06^{\mathrm{b}}$ & \\
& $(0.07-0.18)$ & $(0.05-0.33)$ & \\
\hline
\end{tabular}

Group 1: $n=40$; Group 2: $n=39$ with mean $\pm S D$ and range.

a: Not significantly different between day 0 (baseline) and day 10 .

b: Not significantly different between day 0 (baseline) and day 30 . 
causes increased plasma $\mathrm{Al}$ and has been associated with toxicity (19). Aluminium in antacid form has also been widely prescribed in adults to prevent or treat gastric lesions and reduce the incidence of stress ulceration ( 1 , 2). In all these treatments, $\mathrm{Al}$ absorption depends on the chemical species of Al salts ingested. Aluminium hydroxide (2) and sucralfate (20) are most widely employed as oral $\mathrm{Al}$ medication in antacids for prophylactic or therapeutic use, but few studies other than those of Schïtze et al. (21) have dealt with Al accumulation in patients with normal renal function, particularly when pathological factors modify absorption, as with gastrointestinal symptoms in our study. In fact, De Wolff \& Van der Voet (22) have suggested that intestinal absorption is the main route of $\mathrm{Al}$ entry into the body.

The risk of hyperaluminaemia occurring would appear to be high in our study after long-term therapy with the allantoinate complex containing $128 \mathrm{mg}$ of $\mathrm{Al}$ per formulation (Ulfon Lyoc ${ }^{\circledR}$ or Ulfon ${ }^{\circledR}$ suspension). The four daily samples produced a total of $15360 \mathrm{mg}$ of aluminium ingested by each patient during the 30-day treatment period. In our study, the values recorded in both groups (tables 1 and 2) show that after the 30-day treatment period, there is no increase in plasma and urinary $\mathrm{Al}$, a finding which appears to indicate no $\mathrm{Al}$ accumulation or toxicity conducive to the neuronal disorders attributed to this metal.

These results contrast with findings for other compounds such as Al hydroxide (3), sucralfate in healthy subjects $(23,24)$, or in patients with peptic ulcer disease with normal renal function (21). Kaehny et al. (3) clearly demonstrated high plasma $\mathrm{Al}$ levels in normal adults who ingested $\mathrm{Al}$ hydroxide, as compared with those receiving Al phosphate and controls. More strikingly, Kisters et al. (8) found significantly increased $\mathrm{Al}$ concentrations in the brain tissues of healthy patients with normal kidney function who ingested $2 \mathrm{~g}$ of $\mathrm{Al}$ hydroxide daily for 14 days (total Al load $9682 \mathrm{mg}$ ), as compared with controls. This report showed that $\mathrm{Al}$ entered the brain by passing through the blood-brain barrier. In the light of this study by Kisters et al. (8), Deloncle et al. (25) demonstrated the increased ability of $\mathrm{Al}$ to enter erythrocytes in vitro as well as rat brain in the presence of $L$-glutamate through the formation of a complex capable of crossing membranes.

In healthy subjects receiving sucralfate therapy, very high urinary excretion has been reported after 3 days of administration (26) as well as high plasma concentrations after 21 days (23) or even after 72 hours, in a study using both tablet and suspension formulations (24) corresponding to a total $\mathrm{Al}$ of $828 \mathrm{mg}, 17640 \mathrm{mg}$ and $210 \mathrm{mg}$ respectively. In contrast, Nagy \& Jobst (27) observed an increase in urinary $\mathrm{Al}$ but not in plasma $\mathrm{Al}$ in healthy subjects receiving 18 tablets, each containing 58 $\mathrm{mg}$ of $\mathrm{Al}$ in the form $\mathrm{Al}_{2} \mathrm{Mg}_{4}(\mathrm{OH})_{12} \mathrm{CO}_{3}$ administered during $37 \mathrm{~h}$ (total $\mathrm{Al}$ load $1044 \mathrm{mg}$ ). Weberg \& Berstad (28) concluded the measurement of urinary excretion is a more sensitive method than determination of the plasma level for detecting $\mathrm{Al}$ absorption, which may explain why Kinoshita et al. (29) found no significant increase in plasma concentrations after sucralfate administration in ulcer patients. However, the present study involving patients with gastrointestinal symptoms and normal kidneys showed no significant increase in urinary $\mathrm{Al}$ during the 30-day treatment period, and presumably no increased intestinal absorption since it has been demonstrated that urinary $\mathrm{Al}$ excretion reflects enhanced ingestion (16).

The positive effects of this $\mathrm{Al}$ allantoinate complex in treating gastro-duodenal affections have been demonstrated in man (30), and another study has shown that the healing action is due to allantoin (31). All these experiments were carried out with the "powdered" formulation, and no study on $\mathrm{Al}$ absorption was reported. The pharmaceutical preparation is of considerable interest since the activity of an antacid depends on its miscibility within gastric contents. The suspension form is one of the best pharmaceutical preparations since it allows good contact of the antacid with the stomach's acid phase; the Ulfon Lyoc ${ }^{\circledR}$ form possesses these same properties when kept in contact with buccal mucosa and allowed to dissolve under the tongue.

Our measurements of $\mathrm{Al}$ concentrations in plasma and urine are close to the reference values for healthy subjects reported by Versieck \& Cornelis (14) and Pineau et al. (15). These determinations require high analytical accuracy, precision and reproducibility. Given the ubiquity of this metal and the greater risk of contamination, rigorous, meticulously applied steps were followed from the time of plasma collection, as described by Guillard et al. (10). In addition, analytical performance was monitored by participation in two quality control schemes $(12,13)$ and in conformity with the Worldwide Interlaboratory Aluminium Quality Control program (32). As Hewitt et al. (33) point out, interlaboratory schemes have brought considerable improvement in analytical methods for $\mathrm{Al}$ analysis by enabling laboratories to identify sources of contamination and analytical problems.

We may conclude that administration of $512 \mathrm{mg} \mathrm{Al} \mathrm{per}$ day during 30-day antacid therapy with Ulfon Lyoc ${ }^{\circledR}$ and Ulfon ${ }^{\circledR}$ suspension formulations did not enhance $\mathrm{Al}$ plasma concentration or urinary excretion in patients treated for gastrointestinal symptoms.

\section{Acknowledgements}

We thank Professeur Y. Thomassen, National Institute of Occupational Health, Oslo, Norway, for reviewing the manuscript. In addi- 
tion, we wish to thank Martine Menurd, Annie Marrauld and Katy' Tiphaneau for their skilful technical assistance and Monique Gri- maud and Dominique Decourt for typing the manuscript. This work was supported by the Centre de Recherche des Laboratoires L. Lafon.

\section{References}

1. Weberg R, Berstadt A. Lange O, Schulz T, Aubert E. Duodenal ulcer healing with 4 antacid tablets daily. Scand J Gastroenterol 1985; 20:1041-5.

2. Rydning A. Weberg R, Berstad A, Lange O. Healing of benign gastric ulcer with low-dose antacids and diet. Gastroenterology 1986; 91:56-61.

3. Kaehny WD, Hegg AL, Alfrey AC. Gastrointestinal absorption of aluminium from aluminium-containing antacids. $\mathrm{N}$ Engl $\mathrm{J}$ Med 1977; 296:1389-90.

4. Leung ACT, Henderson IS, Halls DJ, Dobbie JW. Aluminium hydroxide versus sucralfate as a phosphate binder in uraemia. Br Med J 1983; 286:1379-81.

5. Alfrey AC, LeGendre GR, Kaehny WD. The dialysis encephalopathy syndrome. Possible aluminium intoxication. $\mathrm{N}$ Engl $\mathrm{J}$ Med 1976; 294:184-8.

6. Ittel TH, Gladziwa U, Mück W, Sieberth HG. Hyperaluminaemia in critically ill patients: role of antacid therapy and impaired renal function. Eur J Clin Invest 1991; 21:96-102.

7. Kaye $M$. Oral aluminium toxicity in a non-dialyzed patient with renal failure. Clin Nephrol 1983; 20:208-11.

8. Kisters K, Spieker C, Zidek W, Bertram HP, Wessels F, Zumkley $\mathrm{H}$, et al. Clinical aspects of aluminium metabolism and aluminium-containing drugs. Trace Elem Med 1990; 7:62.

9. Cahen R, Pessonnier A. Etude pharmacologique de l'allantoïnate de dihydroxyaluminium et de l'allantoïnate de chlorhydroxyaluminium. Ann Pharm Fr (Paris) 1962; 20:623-36.

10. Guillard $O$, Tiphaneau K, Reiss D, Piriou A. Improved determination of aluminium in serum by electrothermal atomic absorption spectrometry and Zeeman background correction. Anal Lett 1984; 17:1593-605.

11. Griffin RM. Biological monitoring for heavy metals: practical concerns. J Occup Med 1986; 28:615-8.

12. Taylor A, Briggs RJ. An external quality assessment scheme for trace elements in biological fluids. J Anal At Spectrom 1986; 1:391-5.

13. Weber JP. An interlaboratory comparison program for several toxic substances in blood and urine. Sci Total Environ 1988; 71:111-23.

14. Versieck J, Cornelis R. Trace elements in human plasma or serum. Boca Raton: CRC. Press, 1989:65-92.

15. Pineau A. Guillard O, Chappuis P, Arnaud J, Zawislak R. Sampling conditions for biological fluids for trace-element monitoring in hospital patients: a critical approach. Crit Rev Clin Lab Sci 1993; 30:203-22.

16. Alfrey AC. Aluminium and renal disease. Contrib Nephrol $1993 ; 102: 110-24$.

17. Burgess E, Muruve D, Audette R. Aluminium absorption and excretion following sucralfate therapy in chronic renal insufficiency. Am J Med 1992; 92:471-5.

18. Cannata JB, Briggs JD, Junor BJR, Fell GS. Aluminium hydroxide intake: real risk of aluminium toxicity. $\mathrm{Br}$ Med $\mathrm{J}$ 1983; 286:1937-8.

19. Burgess E. Aluminum toxicity from oral sucralfate therapy. Nephron 1991; 59:523-4.

20. McCarthy DM. Sucralfate. New Engl J Med 1991; 325:1917-25.
21. Schütze K, Hentschel E, Happonen P, Akkila J. Sucralfate tablet: treatment of peptic ulcer disease and change in serum aluminium concentration. Hepatogastroenterology 1995; 42:240-5.

22. De Wolff FA, Van der Voet GB. Intestinal absorption of aluminium. In: de Broe ME, Coburn JW, editors. Aluminium and renal failure. Kluwer Academic Publishers: Dordrecht, 1990:41-56.

23. Allain P, Mauras Y, Krari N, Duchier J, Cournot A, Larcheveque J. Plasma and urine aluminium concentrations in healthy subjects after administration of sucralfate. $\mathrm{Br} \mathrm{J}$ Clin Pharmacol 1990; 29:391-5.

24. Conway EL, O'Callaghan $\mathrm{C}$, Drummer $\mathrm{OH}$, Howes LG, Louis WJ. A single-dose comparison of the bioavailability of aluminium from two formulations of sucralfate in normal volunteers. Biopharm Drug Dispos 1994; 15:253-61.

25. Deloncle R, Guillard O, Clanet F, Courtois P, Piriou A. Aluminium transfer as glutamate complex through blood-brain barrier. Biol Trace Elem Res 1990; 25:39-45.

26. Haram EM, Weberg $R$, Berstad A. Urinary excretion of aluminium after ingestion of sucralfate and an aluminium containing antacid in man. Scand J Gastroenterol 1987; 22:615-8.

27. Nagy E, Jobst $K$. The kinetics of aluminium-containing antacid absorption in man. Eur J Clin Chem Clin Biochem 1994; 32:119-21.

28. Weberg R, Berstad A. Gastrointestinal absorption of aluminium from single doses of aluminium-containing antacids in man. Eur J Clin Invest 1986; 16:428-32.

29. Kinoshita H, Kumaki K, Nakano H, Tsuyama R, Nagashima $R$, Okada $M$, et al. Plasma aluminium levels of patients on long-term aluminium therapy. Res Commun Chem Pathol Pharmacol 1982; 35:515-8.

30. Debray $\mathrm{CH}$, Hardouin JP, Chariot J, Lanfranchi J. Etude de dériveés allantoïniques de l'aluminium dans la therapeutique des affections gastroduodenales. Presse Med (Paris) 1962; 70:2643-4.

31. Cahen R, Pessonnier A. Etude de l'allantoinate de dihydroxyaluminium et de l'allantoinate de chlorhydroxyaluminium. Effet sur la cicatrisation de l'ulcère gastrique. Ann Pharm Fr (Paris) 1963; 21:405-11.

32. Guillard O, Pineau A, Baruthio F, Arnaud J. An international quality assessment program for measurement of aluminium in human plasma: a progress report. Clin Chem 1988; 34:1603-4.

33. Hewitt CD, Winborne K, Margrey D, Nicholson JRP, Savory MG, Savory J, et al. Critical appraisal of two methods for determining aluminium in blood samples. Clin Chem 1990; 36:1466-9.

\section{Received March 5/May' 13, 1996}

Corresponding author: Dr. O. Guillard, Ph. D., Laboratoire de Biochimie et de Toxicologie, Hôpital Jean Bernard, BP 577, F-86021 Poitiers Cedex, France 